\title{
Disability and COVID-19: ensuring no one is left behind
}

\author{
Consortium "United Nations workstream on COVID-19 disability inclusive health response and recovery",

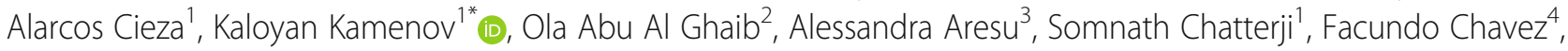 \\ Jarrod Clyne ${ }^{5}$, Nathalie Drew ${ }^{1}$, Michelle Funk', Andrea Guzman', Eleonora Guzzi ${ }^{5}$, Chapal Khasnabis ${ }^{1}$, \\ Bente Mikkelsen ${ }^{1}$, Ren Minghui ${ }^{1}$, Gopal Mitra ${ }^{6}$, Priyanka Narahari ${ }^{7}$, Gisela Nauk ${ }^{8}$, Alice Priddy ${ }^{4}$, Alaa Sabeh ${ }^{8}$, \\ Maria Soledad Cisternas Reyes ${ }^{9}$, Javier Vasquez ${ }^{9}$ and Roxana Widmer-lliescu ${ }^{10}$
}

\begin{abstract}
The United Nations' Sustainable Development Agenda calls for targeted attention to the needs and rights of the most vulnerable populations to ensure a life of dignity and human security for all. In this paper, we argue that persons with disabilities are in a disproportionately vulnerable situation in public health emergencies. By using the example of Coronavirus disease 2019 (Covid-19), we explain why that is and call for the systematic consideration of the needs and rights of persons with disabilities during the response to the outbreak and during the recovery phase. Otherwise, equity will continue to be merely an aspiration during this COVID-19 emergency - as it will in future health emergencies.
\end{abstract}

Keywords: Covid-19, Disability, Health systems

\section{Main text}

Persons with disabilities are a heterogeneous group in terms of identity, gender, age, and underlying health conditions or impairments, and their diversity leads to different health-care needs. For example, children with underlying conditions such as cerebral palsy or muscular dystrophy require early identification and support to allow them to optimize their development and functioning [1]. In their contact with health care services, people with severe vision or hearing impairments require public health information and interventions that are accommodated and accessible [2,3]. People with chronic conditions associated with high levels of disability, such as spinal cord injury, stroke, rheumatoid arthritis or chronic obstructive pulmonary disease often require long-term care delivered by specialized health

\footnotetext{
* Correspondence: kamenovk@who.int

'World Health Organization, Geneva, Switzerland

Full list of author information is available at the end of the article
}

professionals who need to be trained to recognize the specific needs of each person with disability [4-7]. Older persons are likely to experience more impairments associated with frailty that often results in elevated healthcare use and need for caregiver support [8]. Alongside their underlying health conditions and impairments, the environment in which people live will define their experience of disability. Attitudinal and environmental barriers such as inaccessible education, transportation, employment and health care, hinder persons with disabilities to fully and effectively participate in society on an equal basis with others.

Regardless of the diverse nature of the disability, three increased risks are commonly experienced by persons with disabilities during the COVID-19 pandemic: risk in contracting COVID-19, in developing severe symptoms of COVID-19 or dying from the complications of the disease, and of having poorer health during and after the outbreak, whether or not they are infected with COVID19.

(C) The Author(s). 2021 Open Access This article is licensed under a Creative Commons Attribution 4.0 International License, which permits use, sharing, adaptation, distribution and reproduction in any medium or format, as long as you give appropriate credit to the original author(s) and the source, provide a link to the Creative Commons licence, and indicate if changes were made. The images or other third party material in this article are included in the article's Creative Commons licence, unless indicated otherwise in a credit line to the material. If material is not included in the article's Creative Commons licence and your intended use is not permitted by statutory regulation or exceeds the permitted use, you will need to obtain permission directly from the copyright holder. To view a copy of this licence, visit http://creativecommons.org/licenses/by/4.0/ The Creative Commons Public Domain Dedication waiver (http://creativecommons.org/publicdomain/zero/1.0/) applies to the data made available in this article, unless otherwise stated in a credit line to the data. 
Firstly, persons with disabilities are at higher risk of contracting COVID-19 virus, mainly due to environmental barriers that limit effective protection against infection. One such barrier is the lack of timely and accessible public health information that can result either in not receiving the necessary messages or receiving them too late. Few countries and public health organizations distribute guidelines in formats accessible to persons with disabilities - formats including the use of plain language, Easyread formats, electronic screen readers, or captioning and sign language. Also, current public health messaging often does not reach people who are institutionalized or those with mental health and substance use disorders who have limited personal resources, unstable housing conditions, or are homeless [9].

Other barriers relate to the lack of accommodation necessary to facilitate the implementation of basic public health actions, such as frequent handwashing and maintaining physical distance [10]. During the COVID-19 outbreak, locations of superspreading events such as long-term care facilities have been reported in many countries. It has been made clear that in institutional settings where physical distancing is challenging, persons with disabilities are more prone to contracting the disease [11]. This applies also to older persons being cared for in nursing homes or similar facilities where unregulated and poor-quality services, including inadequate infection prevention and control, in some, have led to the spread of the virus and increased mortality $[12,13]$. In fact, data from 31 countries identified through a comprehensive review of available evidence, revealed that the deaths occurring in long-term care institutions as proportion of the total Covid-19 related deaths in the respective countries was extremely high. By September 23,2020 , the average percentage of mortality in institutions was $40.3 \%$ with some countries reaching as high as 85\%. Supplementary Material 1 provides full details for each country.

Secondly, people with underlying health conditions associated with high levels of disability have an increased risk of developing severe symptoms of COVID-19 or dying. The evidence supporting this claim comes from studies that show that people with diabetes mellitus, cerebrovascular disease, chronic obstructive pulmonary disease, and coronary artery disease have a poorer prognosis with COVID-19 [14-18]. Individuals with inflammatory rheumatic disease are also at risk of severe infection due to their immuno-compromised state [19]. In addition, a big proportion of persons with disabilities are over 60 years of age, and as age is one of the strongest risk factors for mortality by Covid-19, persons with disabilities are at particular risk [20]. In fact, published studies show a strong age gradient in the risk of morbidity and mortality from the virus [21], and fatality rates among those over 80 years of age are five times the global average [22].

Despite the increased risks of developing severe symptoms or dying during COVID-19, persons with disabilities have been frequently denied their right to receive the same range of health care as others due to triaging practices in hospitals [23]. This can be seen mainly in overburdened health systems faced with limited supplies of resources, such as emergency care beds and ventilators [24-26]. Denial of COVID-19 treatment based on disability can be seen in many countries; in the United States, for example, the Alabama guidelines recommended that hospitals withhold ventilators from "patients with severe or profound mental retardation", dementia, or severe traumatic brain injury, whereas Utah guidelines recommended excluding patients with advanced neuromuscular diseases who require assistance with activities of daily living [27, 28]. Such discriminatory decisions contributed to the disproportionately high mortality rates amongst persons with disabilities. In the United Kingdom, statistics showed that persons with disabilities accounted for 59\% of all COVID-19 deaths in the country [29]. In addition to the denial of health care, more and more evidence for amplified aggression and coercion within the health sector towards persons with psychosocial disabilities can be seen in many countries during the pandemic, leading to severe consequences including violence and even death [30].

Thirdly, persons with disabilities have an increased risk of poorer health during and after the outbreak even without contracting COVID-19. This is because of measures some countries have relied on to control the outbreak. Country lockdowns can lead to restricted access to public spaces, making it harder to undertake healthy behaviors, such as physical activity or socializing. Social distancing during the pandemic has been harder for people with vision impairment, and the common use of face masks have affected the ability of people with hearing loss to lip read and communicate. These measures have also affected the access to medicines, health products or event food for persons with disabilities [31]. Very often restrictions have severely affected the mental health state of millions of people who have not received adequate services to address their needs [32]. Country measures have even more severe health deteriorating consequences when health is already compromised [33]. People living with dementia, for example, can feel lonely and withdrawn and their cognitive states can deteriorate since they may have little experience with telecommunication and depend primarily on in-person support [34]. Individuals with neurodevelopmental conditions such as Attention Deficit Hyperactivity Disorder (ADHD), being particularly vulnerable to the physical distancing 
measures, may feel increasingly distressed and anxious by the restrictions [35]. Furthermore, disruptions in the provision of social care have had a devastating impact on persons with disabilities who rely on it, and many have had to rely on the support of their families. The closure of day centers or any other means of socialization has left persons with disabilities isolated [36]. Also, children with special and educational needs and disabilities have been excluded from receiving education in some countries because of lack of accessible information and educational materials in accessible formats [31].

In addition, poorer health is associated with reducing essential health services to an absolute minimum during the COVID-19 outbreak. A person with a disability may require frequent access to health-care services due to their underlying health conditions [2]; disruption to these services puts them at a disadvantage in maintaining their general health. In China, persons with psychosocial disabilities who usually visit psychiatric outpatient clinics on a monthly basis to obtain maintenance medications have been frequently denied access due to mass quarantines and restrictions to public transport [37]. Table 1 summarizes the main risks that persons with disabilities commonly experience during the current Covid-19 pandemic, the factors and barriers associated with these risks, and the main areas where the actions in the post-pandemic era need to focus.

To respond to these challenges, targeted actions to mitigate the risks and secure the rights of persons with disabilities, including the rights to life and to the highest attainable standard of health during the COVID-19 outbreak have already been proposed in various documents, including recent guidance from the United Nations Secretary General's office and the World Health
Organization [38-43]. Those actions need urgently to be put into practice.

Governments, the public health community, all professionals providing COVID-19-related care and general health care, as well as civil society need to look beyond the current public health crisis and consider now how to build back better our health systems so that they are more inclusive for everyone - including persons with disabilities. The health sector response needs to target three main areas - access to health services, disability-inclusive national emergency preparedness and response plans, and disability-inclusive cross-sectorial public health interventions. The long-term outcome of COVID-19 must be to set a new precedent by building universally designed health systems, inclusive economies, systems rooted in the communities, reaching out and empowering persons with disabilities and guaranteeing equal opportunities for all [44]. This can only be achieved if the Sustainable development Goals (SDGs) in general and SDG 3 in particular include targeted disability-inclusive measures in line with the UN Convention on the Rights of Persons with Disabilities.

For the implementation of SDG 3 there is a proposed Global Action Plan with seven key accelerators of progress [45]. All these accelerators need to be disabilityinclusive, if we want to ensure that persons with disabilities are not left behind by the health sector, especially during future health emergencies. These are some actions that need to be included:

\section{Universally accessible primary health care}

Free or affordable, effective and sustainable primary health care is the cornerstone to achieving the healthrelated SDG targets for everyone. Primary health care brings health services, facilities and goods closer to

Table 1 Risks experienced by persons with disabilities in the Covid-19 pandemic, barriers associated with the risks and key response areas for the post-pandemic era

\begin{tabular}{|c|c|c|}
\hline Risks & Factors associated with the risks & Response \\
\hline Contracting Covid-19 & $\begin{array}{l}\text { Societal: } \\
\text { - Lack of timely and accessible public health } \\
\text { information } \\
\text { - Lack of accommodation to facilitate the } \\
\text { implementation of basic public health actions } \\
\text { - Lack of effective protection measures in } \\
\text { institutionalized care }\end{array}$ & $\begin{array}{l}\text { - Access to health services which includes removing any } \\
\text { communication, physical and attitudinal barriers } \\
\text { - Disability-inclusive national emergency preparedness and re- } \\
\text { sponse plans } \\
\text { - Disability-inclusive cross-sectorial public health interventions } \\
\text { that target various determinants of health }\end{array}$ \\
\hline $\begin{array}{l}\text { Developing severe } \\
\text { symptoms or dying }\end{array}$ & $\begin{array}{l}\text { Biomedical: } \\
\text { - Preexisting health condition and comorbidities } \\
\text { Societal: } \\
\text { - Denied healthcare because of triaging practice }\end{array}$ & \\
\hline $\begin{array}{l}\text { Poorer health during and } \\
\text { after pandemic }\end{array}$ & $\begin{array}{l}\text { Societal: } \\
\text { - Measures to control the outbreak without } \\
\text { accommodation } \\
\text { - Exacerbated impact of lack of physical activity and } \\
\text { social contacts } \\
\text { - Reduction of essential health services and social care }\end{array}$ & \\
\hline
\end{tabular}


where people live and work and links those services to higher levels of care. Providing barrier-free access to primary health care is therefore a fundamental right for everyone but especially for those requiring services on a regular basis, as is the case for some persons with disabilities. In addition to the accessible primary health care, all service delivery within the health systems should be appropriately and proportionately delivered to all people on an equal basis. This includes equitable access to COVID-19 vaccination and ensuring that equity in access is a guiding principle for all immunization programmes [46].

\section{Sustainable and accessible financing for health with social protection programmes}

Sustainable and accessible financing that reduces the unmet need for health services and the financial hardship to users from out-of-pocket payments and disproportionate economic hardship need to be complemented by social protection programmes, so that extra costs of medicines, assistive products or personal support can be covered without incurring penalties for decrements in health and functioning.

\section{Inclusive community and civil society engagement}

Persons with disabilities and their family members or caregivers can present their experience, perspective and expertise to knowledge-generation and policymaking. However, to meaningfully participate in the design, implementation and monitoring of health systems, accessibility, non-discrimination, and support if requested, must be ensured. Adopting this approach not only achieves accountability but ensures that no one is left behind.

\section{Proportionate universalism in determinants of health}

Determinants of health need to be addressed in such a way that everyone is included in health interventions and public health strategies. The nature, scale and intensity of the interventions must equate to the nature, scale and intensity of the specific needs of those experiencing disability so that the outcome is equal for all. This is vital for ensuring that gains are maximized for everyone equally across the SDGs, including persons with disabilities.

\section{Innovative programming in fragile and vulnerable settings}

A disability-inclusive humanitarian response must be based on thorough analysis of the needs and factors contributing to the heightened risks faced by persons with disabilities, including age, gender and barriers they encounter in accessing health care and assistance in a humanitarian context, such as a pandemic. The strategic response includes mainstreaming interventions to ensure accessibility to all (e.g. making "Water, sanitation and hygiene (WASH)" facilities physically accessible to all) and addressing disability-related needs directly (e.g. ensuring the provision of assistive products) to ensure that persons with disabilities have access to health services on an equal basis with others [47].

\section{Innovation and universal access}

Innovation is critical to improving the quality and efficiency of public services; sustainable and equitable access ensures better availability of services to those who need them most. It is, therefore, paramount that any newly developed or re-formed services innovate their thinking as regards inclusion and ensure that persons with disabilities have equitable access to information in accessible formats, facilities, programmes, services and goods.

\section{Data and digital health}

Good quality, comprehensive, accessible and appropriately disaggregated data are necessary to understand the needs and current situation of persons with disabilities. Such data can show, for example, whether persons with disabilities die more often because of COVID-19, which includes identifying the barriers they face in accessing healthcare interventions and the health consequences of this. This information is key to designing inclusive programmes, policies and legislation, guiding investment and public decisions, and measuring progress. Digital technologies must be made accessible for all. During the COVID-19 outbreak, for example, information on symptom tracking, contact tracing or testing, delivered through digital technology needs to be made accessible so that disability-related data can also be collected.

\section{Conclusion}

COVID-19 has created a human crisis on an unprecedented scale, which has disproportionately impacted persons with disabilities. Nonetheless, the pandemic provides an opportunity to build better and more equitable health sector where everyone has equal access to information, facilities, programmes, services and goods, and where nobody is left behind. Current available health services must embrace more digital technology to deliver Digitally Enhanced Healthcare with virtual or remote services to ensure Good Health and Well-being of the persons with disabilities. It is evident that the targets of SDG 3 cannot be met without accelerated progress in addressing health disparities, mitigating digital divide and reducing vulnerability across countries. Therefore, the rights and needs of persons with disabilities need to be recognized by policymakers and the entire healthcare sector as being essential to achieving SDG 3 and universal health coverage. 


\section{Abbreviations}

Covid-19: Coronavirus disease 2019; ADHD: Attention Deficit Hyperactivity Disorder; SDGs: Sustainable development Goals; WASH: Water, sanitation and hygiene

\section{Supplementary Information}

The online version contains supplementary material available at https://doi. org/10.1186/s13690-021-00656-7.

Additional file 1 Table 1. Covid-19 related mortality in long-term care institutions: results from a comprehensive review (Updated: September $23,2020)$.

\section{Acknowledgements}

This publication was produced in the context of the Global Programme Supporting Disability Inclusive COVID-19 Response and Recovery at National Level supported by the United Nations Partnership on the Rights of Persons with Disabilities Multi Partner Trust Fund (UNPRPD MPTF). The authors alone are responsible for the views expressed in this article and they do not necessarily represent the views, decisions or policies of the institutions with which they are affiliated. This publication does not necessarily reflect the official position of the UNPRPD MPTF.

\section{Authors' contributions}

All authors participated equally in the preparation and writing of this manuscript. All authors read and approved the final manuscript.

\section{Funding}

No funding is to be declared for this study.

\section{Availability of data and materials}

All data generated or analysed during this study are included in this published article [and its supplementary information files].

\section{Declarations}

Ethics approval and consent to participate

Not applicable.

\section{Consent for publication}

Not applicable.

\section{Competing interests}

The authors declare that they have no competing interests.

\section{Author details}

${ }^{1}$ World Health Organization, Geneva, Switzerland. ${ }^{2}$ UN Partnership on Persons with Disabilities Fund, United Nations Development Program, New York, USA. ${ }^{3}$ International Disability and Development Consortium, Brussels, Belgium. ${ }^{4}$ Office of the United Nations High Commissioner for Human Rights, Geneva, Switzerland. ${ }^{5}$ International Disability Alliance, Geneva, Switzerland. ${ }^{6}$ Executive Office of the Secretary-General, United Nations, New York, USA. ${ }^{7}$ United Nations Entity for Gender Equality and the Empowerment of Women, New York, USA. ${ }^{8}$ Economic and Social Commission for Western Asia, Beirut, Lebanon. ${ }^{9}$ Special Envoy of the United Nations Secretary General on Disability and Accessibility, New York, USA. ${ }^{10}$ International

Telecommunication Union, Geneva, Switzerland.

\section{Received: 8 February 2021 Accepted: 10 July 2021}

\section{Published online: 20 August 2021}

\section{References}

1. Kuper H., \& Heydt P. The missing billion: access to health services for 1 billion people with disabilities. London school of hygiene and tropical medicine 2019.

2. World Health Organization. World Report on Disability. World Health Organization 2011.

3. World Health Organization. World Report on Vision. World Health Organization 2019
4. Fehlings MG, Tetreault LA, Wilson, et al. A clinical practice guideline for the management of acute spinal cord injury: introduction, rationale, and scope 2017.

5. Dobkin BH. Rehabilitation after stroke. N Engl J Med. 2005;352(16):1677-84

6. Smolen JS, Aletaha D, McInnes IB. Rheumatoid arthritis. Lancet. 2016; 388(10055):2023-38. https://doi.org/10.1016/S0140-6736(16)30173-8.

7. Celli BR, Wedzicha JA. Update on clinical aspects of chronic obstructive pulmonary disease. N Engl J Med. 2019;381(13):1257-66. https://doi.org/10.1 056/NEJMra1900500

8. World Health Organization. World report on ageing and health. World Health Organization 2015.

9. Karamouzian M, Johnson C, Kerr T. Public health messaging and harm reduction in the time of COVID-19. Lancet Psychiatry. 2020;7(5):390-1. https://doi.org/10.1016/S2215-0366(20)30144-9.

10. World Health Organization. Coronavirus disease (COVID-19) advice for the public. World Health Organization 2020. Available at: https://www.who.int/ emergencies/diseases/novel-coronavirus-2019/advice-for-public

11. Independent. It was a medical disaster: The psychiatric ward that saw 100 patients diagnosed with new coronavirus. 2020; Available at: https://www. independent.co.uk/news/world/asia/coronavirus-south-korea-outbreakhospital-patients-lockdown-a9367486.html

12. Boodman E, Branswell H. First Covid-19 outbreak in a US nursing home raises concerns. 2020; Available at: https://www.statnews.com/2020/02/29/ new-covid-19-death-raises-concerns-about-virus-spread-in-nursing-homes/

13. Lloyd-Sherlock P., Ebrahim S., Geffen L., \& McKee M. Bearing the brunt of covid-19: older people in low and middle income countries. 2020.

14. Pal R, Bhadada SK. COVID-19 and non-communicable diseases. Postgrad Med J. 2020;96(1137):429-30. https://doi.org/10.1136/postgradmedj-2020-13 7742.

15. Guan WJ, Ni ZY, Hu Y, Liang WH, Ou CQ, He JX, et al. Clinical characteristics of coronavirus disease 2019 in China. N Engl J Med. 2020;382(18):1708-20. https://doi.org/10.1056/NEJMoa2002032

16. Yang J, Zheng Y, Gou X, Pu K, Chen Z, Guo Q, et al. Prevalence of comorbidities in the novel Wuhan coronavirus (COVID-19) infection: a systematic review and meta-analysis. Int J Infect Dis. 2020;94:91-5. https:// doi.org/10.1016/j.jijid.2020.03.017.

17. Yang $X, Y u Y, X u J$, Shu $H$, Xia J', Liu H, et al. Clinical course and outcomes of critically ill patients with SARS-CoV-2 pneumonia in Wuhan, China: a single-centered, retrospective, observational study. Lancet Respir Med. 2020; 8(5):475-81. https://doi.org/10.1016/S2213-2600(20)30079-5.

18. Wang D, Hu B, Hu C, Zhu F, Liu X, Zhang J, et al. Clinical characteristics of 138 hospitalized patients with 2019 novel coronavirus-infected pneumonia in Wuhan, China. Jama. 2020;323(11):1061-9. https://doi.org/10.1001/jama.2020.1585.

19. Gianfrancesco MA, Hyrich $\mathrm{KL}$, Gossec $\mathrm{L}$, et al. Rheumatic disease and COVID19: initial data from the COVID-19 global rheumatology alliance provider registries. Lancet Rheumatol. 2020;2(5):e250-e253.

20. Pijls BG, Jolani S, Atherley A, Derckx RT, Dijkstra JI, Franssen GH, et al. Demographic risk factors for COVID-19 infection, severity, ICU admission and death: a meta-analysis of 59 studies. BMJ Open. 2021:11(1):e044640. https://doi.org/10.1136/bmjopen-2020-044640.

21. Verity R, Okell LC, Dorigatti I, Winskill P, Whittaker C, Imai N, et al. Estimates of the severity of coronavirus disease 2019: a model-based analysis. Lancet Infect Dis. 2020;20(6):669-77. https://doi.org/10.1016/S1473-3099(20)30243-7.

22. World Health Organization. COVID-19 Strategy update. World Health Organization 2020; Available at: https://www.who.int/docs/default-source/ coronaviruse/covid-strategy-update-14april2020.pdf?sfvrsn=29da3ba0_12

23. Truog RD, Mitchell C, Daley GQ. The toughest triage - allocating ventilators in a pandemic. N Engl J Med. 2020;382(21):1973-5. https://doi. org/10.1056/NEJMp2005689.

24. Emanuel EJ, Persad G, Upshur R, Thome B, Parker M, Glickman A, et al. Fair allocation of scarce medical resources in the time of Covid-19. N Engl J Med. 2020;382(21):2049-55. https://doi.org/10.1056/NEJMsb2005114.

25. Vergano M, Bertolini G, Giannini A, et al. Clinical ethics recommendations for the allocation of intensive care treatments in exceptional, resourcelimited circumstances: the Italian perspective during the COVID-19 epidemic. Recenti Prog Med. 2020;111(4):207.

26. Mounk Y. The extraordinary decisions facing Italian doctors. Atlantic. 2020; Available at: https://www.theatlantic.com/ideas/archive/2020/03/who-getshospital-bed/607807/.

27. Mello M, et al. Respecting Disability Rights - Towards Improved Crisis Standards of Care. N Engl J Med. 2020;383:e26. 
28. Pendo E. Covid-19 and disability-based discrimination in health care, American Bar association, 2020.

29. UK Office of National Statistics. COVID19 related deaths by disability status in England and Wales. 2020. Updated 18 September 2020.

30. Times of Malta. The policing of mental health. Available at: https:// timesofmalta.com/articles/view/the-policing-of-mental-health.792902

31. Shakespeare T, Ndagire F, Seketi QE. Triple jeopardy: disabled people and the COVID-19 pandemic. Lancet (London, England). 2021;397(10282):1331-3.

32. Special Envoy of the UNSG on Disability and Accessibility. 2020. Joint Statement: Mental Health of Persons with Disabilities during the COVID-19 pandemic.

33. Kluge HHP, Wickramasinghe K, Rippin HL, Mendes R, Peters DH, Kontsevaya $\mathrm{A}$, et al. Prevention and control of non-communicable diseases in the COVID-19 response. Lancet. 2020;395(10238):1678-80. https://doi.org/10.101 6/S0140-6736(20)31067-9.

34. Wang H, Li T, Barbarino P, Gauthier S, Brodaty H, Molinuevo JL, et al. Dementia care during COVID-19. Lancet. 2020;395(10231):1190-1. https:// doi.org/10.1016/S0140-6736(20)30755-8.

35. Cortese S, Asherson P, Sonuga-Barke E, Banaschewski T, Brandeis D, Buitelaar $J$, et al. ADHD management during the COVID-19 pandemic: guidance from the European ADHD guidelines group. The Lancet Child \& Adolescent Health. 2020;4(6):412-4. https://doi.org/10.1016/S2352-4642(20)30110-3.

36. Europe I. Neglect and discrimination multiplied how COVID-19 affected the rights of people with intellectual disabilities and their families. Brussels: Inclusion Europe; 2020. https://www.inclusion-europe.eu/wp-content/uploa ds/2020/11/COVID-report-Final.pdf (

37. Yang Y, Li W, Zhang Q, Zhang L, Cheung T, Xiang YT. Mental health services for older adults in China during the COVID-19 outbreak. Lancet Psychiatry. 2020;7(4):e19. https://doi.org/10.1016/S2215-0366(20)30079-1.

38. World Health Organization. Disability considerations during the COVID-19 outbreak. World Health Organization 2020. Available at: https://www.who. int/who-documents-detail/disability-considerations-during-the-covid-19outbreak

39. United Nations Human Rights Office of the High Commissioner. Covid-19 and the rights of persons with disabilities: guidance. 2020. Available at: https://www.ohchr.org/Documents/lssues/Disability/COVID-19_and_The_ Rights_of_Persons_with_Disabilities.pdf?fbclid=IwAR2k4WVrFxgLiKXDUA nfRb509X_NDFux_wYm1LOoXBW1tyNfKwBWOHYtYk4

40. Armitage $R$, Nellums LB. The COVID-19 response must be disability inclusive Lancet Public Health. 2020;5(5):e257. https://doi.org/10.1016/S2468-2667(2 0)30076-1.

41. Kuper H, Banks LM, Bright T, Davey C, Shakespeare T. Disability-inclusive COVID-19 response: what it is, why it is important and what we can learn from the United Kingdom's response. Wellcome Open Research. 2020;5(79): 79. https://doi.org/10.12688/wellcomeopenres.15833.1.

42. Pineda VS, Corburn J. Disability, urban health equity, and the coronavirus pandemic: promoting cities for all. J Urban Health. 2020;97(3):336-41.

43. United Nations Policy brief: a disability-inclusive response to COVID-19. United Nations 2020

44. United Nations. Shared responsibility global solidarity: responding to the socio-economic impacts of COVID-19. 2020. Available at: https://unsdg.un. org/sites/default/files/2020-03/SG-Report-Socio-Economic-Impact-of-Covid1 9.pdf

45. World Health Organization. The global action plan for healthy lives and well-being for all: strengthening collaboration among multilateral organizations to accelerate country progress on the health-related sustainable development goals. No. WHO/DGO/GAP/19.1. World Health Organization 2019.

46. World Health Organization \& United Nations Children's Fund (UNICEF). Disability considerations for COVID-19 vaccination: WHO and UNICEF policy brief. 2021. World Health Organization.

47. UNICEF. Guidance on strengthening disability inclusion in Humanitarian Response Plans. UNICEF 2019.

\section{Publisher's Note}

Springer Nature remains neutral with regard to jurisdictional claims in published maps and institutional affiliations.

\section{Ready to submit your research? Choose BMC and benefit from:}

- fast, convenient online submission

- thorough peer review by experienced researchers in your field

- rapid publication on acceptance

- support for research data, including large and complex data types

- gold Open Access which fosters wider collaboration and increased citations

- maximum visibility for your research: over $100 \mathrm{M}$ website views per year

At BMC, research is always in progress.

Learn more biomedcentral.com/submissions 